\begin{tabular}{|c|c|c|c|c|c|c|}
\hline \multirow{3}{*}{$\begin{array}{l}\text { 2. ECN Category } \\
\text { (mark one) } \\
\text { Supplemental } \\
\text { Direct Revision } \\
\text { Change ECN } \\
\text { Temporary } \\
\text { Standby } \\
\text { Supersedure } \\
\text { Cancel/Void }\end{array}$} & \multirow{3}{*}{$\begin{array}{r}{[]} \\
{[x]} \\
{[]} \\
{[]} \\
{[]} \\
{[]} \\
{[]}\end{array}$} & \multicolumn{2}{|c|}{$\begin{array}{l}\text { 3. Originator's Name, Organization, MSIN, } \\
\text { and Telephone No. } \\
\text { Clarence Homi, Evaluation and } \\
\text { Planning, R2-12. } 373-1097\end{array}$} & \multicolumn{2}{|c|}{$\begin{array}{l}\text { 3a. USe Required? } \\
{[] \text { Yes }[X] \text { Ho }}\end{array}$} & $\begin{array}{l}\text { 4. Date } \\
05 / 09 / 96\end{array}$ \\
\hline & & \multicolumn{2}{|c|}{$\begin{array}{l}\text { 5. Project Title/No./Work Order No. } \\
\text { Tank 241-S-111 }\end{array}$} & \multicolumn{2}{|c|}{$\begin{array}{l}\text { 6. Bldg./Sys./Fac. No. } \\
241-5-111\end{array}$} & $\begin{array}{l}\text { 7. Approval Designator } \\
N / A\end{array}$ \\
\hline & & \multicolumn{2}{|c|}{$\begin{array}{l}\text { 8. Document Numbers Changed by this ECN } \\
\text { (includes sheet no. and rev.) } \\
\text { WHiC-SD-Wil-TP-317, ReV. O-B }\end{array}$} & \multicolumn{2}{|c|}{$\begin{array}{l}\text { 9. Related ECN Ho(s). } \\
\text { ECNs: } 625426 \text {. } \\
625775\end{array}$} & $\begin{array}{l}\text { 10. Related PO No. } \\
\qquad N / A\end{array}$ \\
\hline \multicolumn{2}{|c|}{$\begin{array}{l}\text { 11a. Modification Work } \\
\text { [] Yes (fill out Blk. } \\
\text { 11b) } \\
{[X] \text { No (NA Blks. 11b, }} \\
11 c_{1}, 11 d \text { ) }\end{array}$} & $\begin{array}{l}\text { 11b. Work Packégs } \\
\text { No. } \\
\text { N/A }\end{array}$ & \multicolumn{2}{|c|}{$\begin{array}{l}\text { 11c. Modification work Complete } \\
\text { N/A }\end{array}$} & \multicolumn{2}{|c|}{$\begin{array}{l}\text { 11d. Restored to Original Condi- } \\
\text { tion (Temp. or Standby ECN only) } \\
\text { N/A }\end{array}$} \\
\hline
\end{tabular}

12. Description of change

Complete revision.

13a. Justification (mark one)
$\begin{array}{llllllll}\text { Criteria Change [X] } & \text { Design Improvement } & {[]} & \text { Environmental } & \text { [] } & \text { Facility Deactivation } \\ \text { As-Found } & {[]} & \text { Facilitate Const } & {[]} & \text { Const. Error/Omission } & {[]} & \text { Design Error/Omission } & \text { [] }\end{array}$

13b. Justification Details

Changed to comply with new template and DOE-RL recommended modifications.

14. Distribution (include name, MS!N, and no. of copies) See attached distribution.

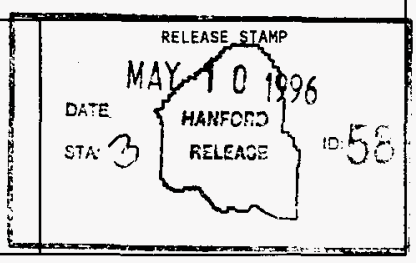

A-7900-013-2 (11/94) GEF095 


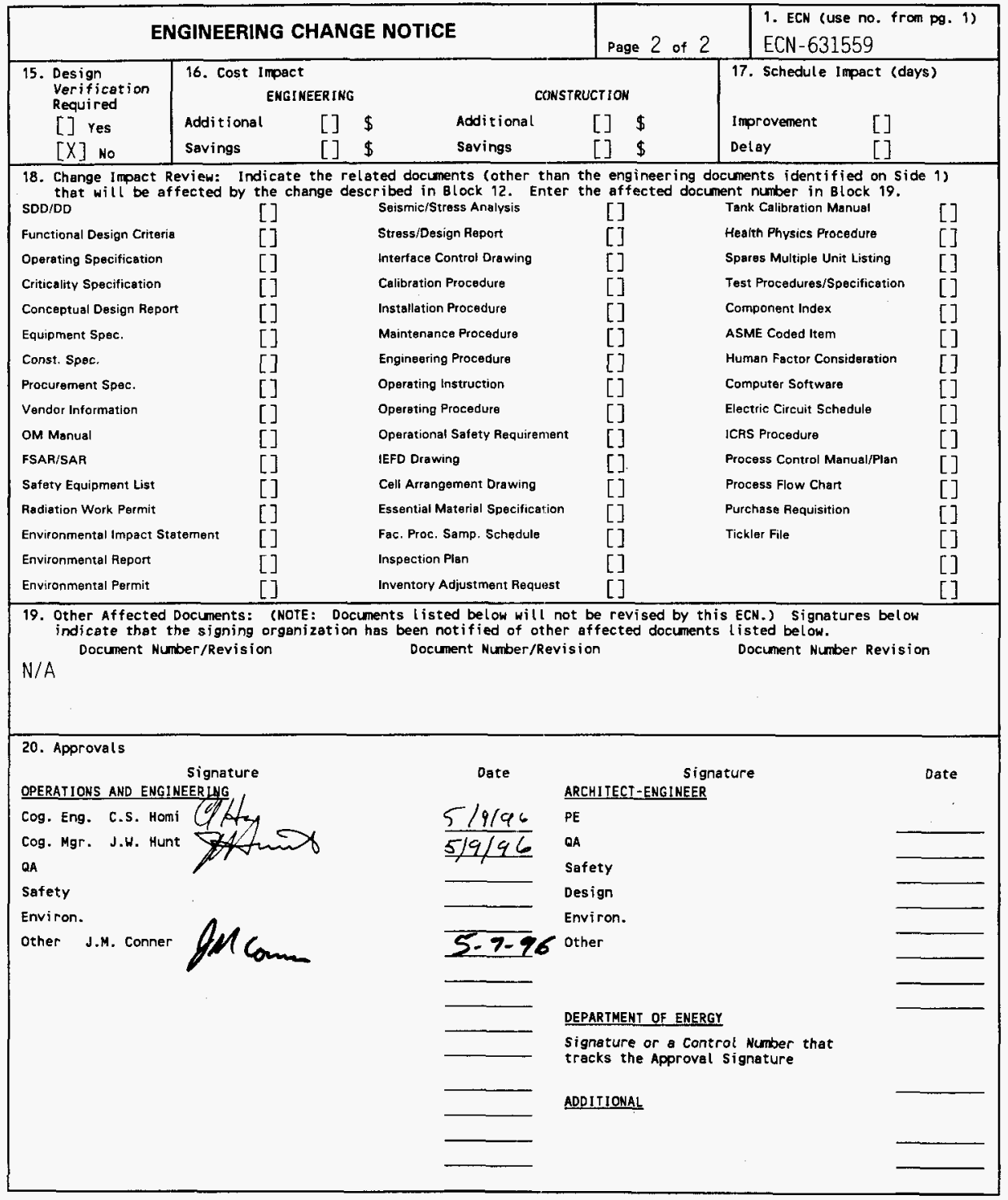


WHC-SD-WM-TP-317, Rev. 1

\title{
Tank 241-S-111 Tank Characterization Plan
}

\author{
C. 5. Homi
}

West inghouse Hanford Company, Richland, WA 99352

U.S. Department of Energy Contract DE-AC06-87RL10930

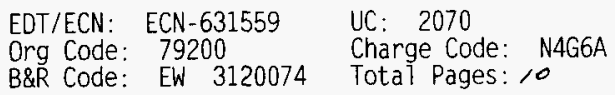

Key Words: Characterization. General Safety Issues, Specific Safety Issues, Information Requirements. Schedule

Abstract: This document is a plan that identifies the information needed to address relevant issues concerning short-term and long-term storage and long-term management of single-shell tank 241-5-111.

TRADEMARK DISCLAIMER. Reference herein to any specific commercial product, process, or service by trade name, trademark, manufacturer, or otherwise, does not necessarily constitute or imply its endorsement, recommendation, or favoring by the United states Govermment or any agency thereof or its contractors or subcontractors.

Printed in the United States of America. To obtain copies of this document, contact: WHC/BCS Document Control Services, P.0. Box 1970, Mailstop H6-08, Richland WA 99352, Phone (509) 372-2420; Fax (509) 376-4989.
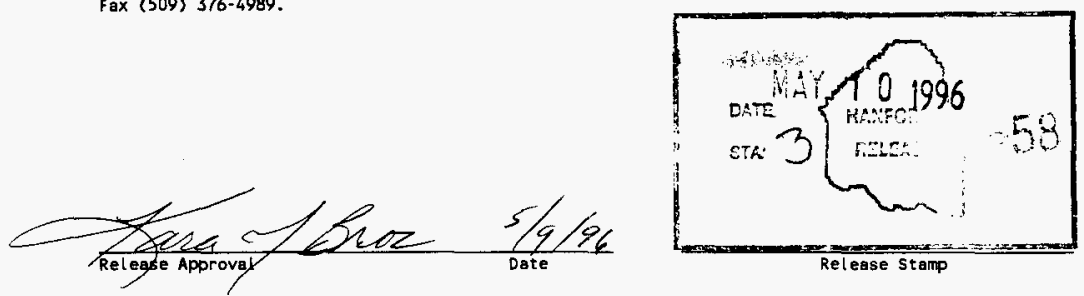

\section{Approved for Public Release}




\section{RECORD OF REVISION}

(1) Document Number

WHC-SD-WM-TP-317

Page 1

(2) Title

TANK 241-S-111 TANK CHARACTERIZATION PLAN

CHANGE CONTROL RECORD

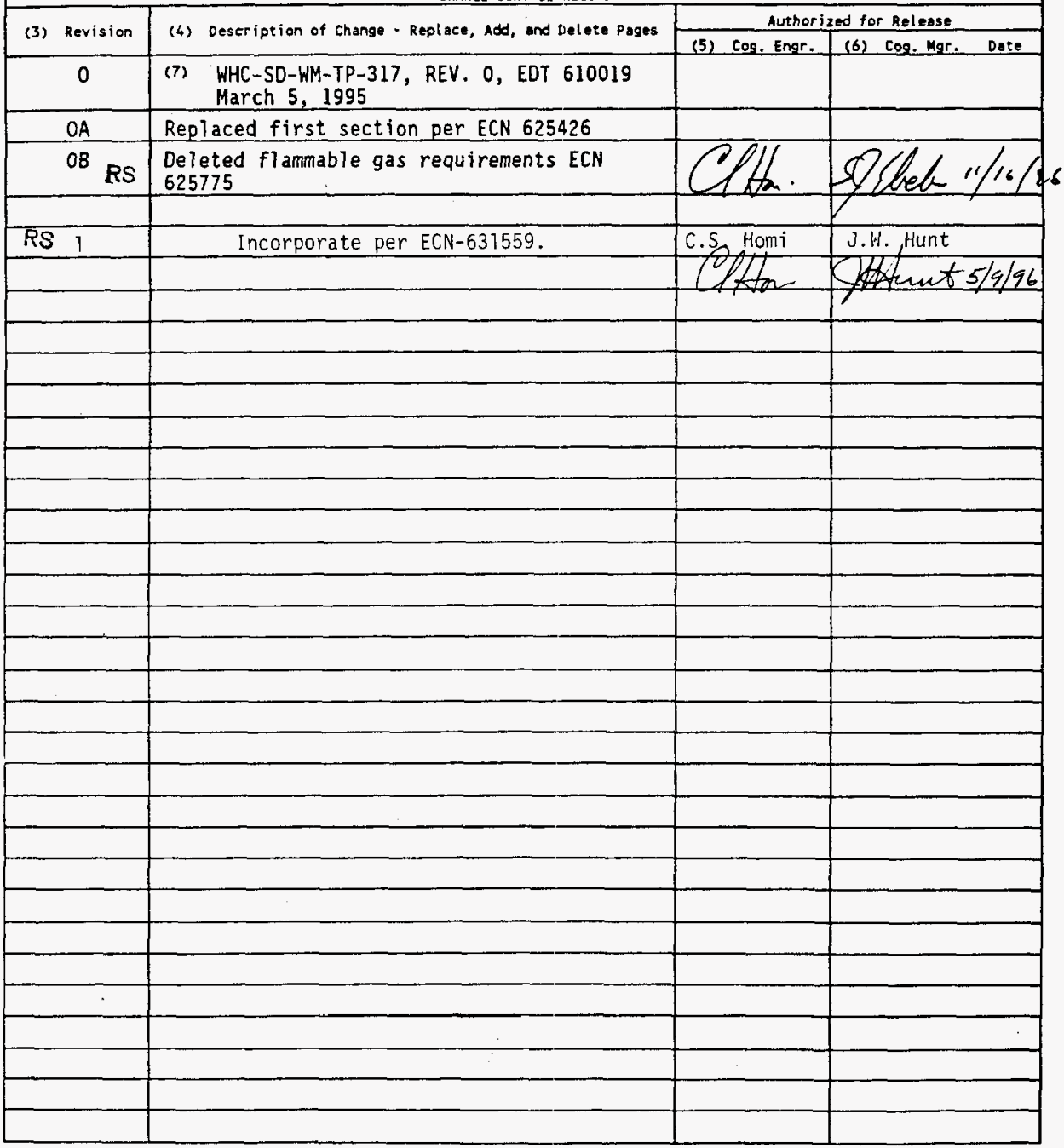


WHC-SD-WM-TP-317

Revision 1

UC-2070

\section{Tank 241-S-111 \\ Tank Characterization Plan}

J. M. Conner

Westinghouse Hanford Company

Date Published

May 1996

Prepared for the U.S. Department of Energy

Office of Environmental Restoration and

Waste Management

\section{(20) Westinghouse p. Bax 1970 Hanford Company Rienhand, Wastingon}

Manzgement and Operations Contractor for the

U.S. Department of Energy under Contract DE-AC06-87RL10930

Approved for Public Release 
WHC-SD-WM-TP-317, REV 1

TABLE OF CONTENTS

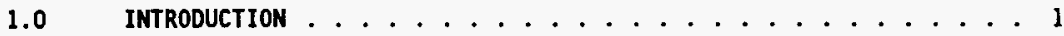

2.0 PROGRAM ELEMENTS REQUIRING INFORMATION FOR TANK 241-S-111 . . . . 1

2.1 GENERAL SAFETY ISSUES . . . . . . . . . . . . . . . . 1

2.2 SPECIFIC SAFETY ISSUES . . . . . . . . . . . . . . 2

2.2.1 Ferrocyanide ................. 2

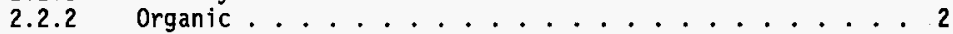

2.2.3 High Heat................... 2

2.2.4 Flammable Gas.................. 2

2.2.5 Vapor..................... 2

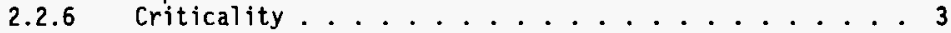

2.3 CONTINUING OPERATIONS .................. 3

2.3.1 Compatibility/Stabilization ............ 3

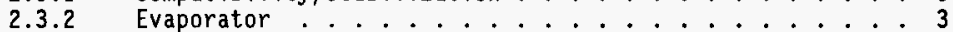

2.4 DOUbLE-SHELL TANK WaSte ANALYSIS PLAN . . . . . . . . . . . . 3

2.5 DISPOSAL ...................... 3

2.5.1 Retrieval .................. 3

2.5.2 Pretreatment/vitrification $\ldots$

2.6 HISTORICAL MODEL EVALUATION ................. 4

3.0 HOW INFORMATION WILL BE OBTAINED .................. 4

4.0 PRIORITY OF INFORMATION REQUIREMENTS ................ 4

5.0 WHEN INFORMATION WILL BE AVAILABLE $\ldots \ldots \ldots$

6.0 REFERENCES ........................ 6

\section{LIST OF TABLES}

4-1 Integrated DQO Requirements and Priorities ...........5 
WHC-SD-WM-TP-317, REV 1

\subsection{INTRODUCTION}

This Tank Characterization Plan (TCP) identifies the information needed to address relevant issues concerning short-term and long-term safe storage and long-term management of single shell tank 24l-S-111 (S-111). It should be understood that the various needs and issues surrounding tank S-11l are evolving as new information about the tank is uncovered. As a result of this progression, this TCP addresses only the issues that, to this date, have been identified. It is expected that deviations from this plan may occur as additional issues or needs arise which impact the management of tank S-111. As necessary, this TCP will be revised to reflect those changes or deviations. This plan reflects the best information available as of May 1996.

Tank S-111 was constructed between 1950 and 1951. The tank began receiving waste in 1952. Over its service life, the tank received mainly waste from the Reduction Oxidation (REDOX) facility and evaporator bottoms. The tank is sound and interim stabilization has not yet been performed (Brevick, et al. 1994).

Tank S-111 contains a total waste volume of $2326 \mathrm{~kL}$ (596 kgal), which is equivalent to $569 \mathrm{~cm}(224 \mathrm{in})$ of waste as measured from the basel ine of the tank (Hanton 1996).

This tank is on the Flammable Gas and Organic Watch Lists.

Near-term sampling and analysis activities are focused on either verifying or changing the Watch List tank status, and identifying any new safety issues. Should any safety issues be identified, additional analys is will occur consistent with the identified issue.

In addition to the resolution of the safety issues, it is intended that all tank waste will be subjected to pretreatment and retrieval to prepare for final storage or disposal. Presently, these long-range plans have yet to be fully identified and are, therefore, not included in this document.

\subsection{PROGRAM ELEMENTS REQUIRING INFORMATION FOR TANK 241-S-111}

This section identifies the various program elements, and identifies which of these programs require characterization data from tank S-111.

\subsection{GENERAL SAFETY ISSUES}

The Tank Safety Screening Data Quality Objective (Dukelow et al. 1995) describes the sampling and analytical requirements that are used to screen waste tanks for unidentified safety issues. Analytical requirements for the safety screening of a tank are energetics, total alpha activity, moisture content, density and flammable gas concentration. 
WHC-SD-WM-TP-317, REV 1

\subsection{SPECIFIC SAFETY ISSUES \\ 2.2.1 Ferrocyanide}

This tank is not on the Ferrocyanide Watch List; therefore, no information needs are currently identified for this program element.

\subsubsection{Organic}

This tank is on the Organic Watch List. Sampling and analysis requirements must be performed per the Data Quality Objective to Support Resolution of the Organic Complexant Safety Issue (Turner et al. 1995). The analyses employed will determine the total organic carbon (TOC), energetics, presence of a free organic liquid phase, and moisture content.

\subsubsection{High Heat}

This tank is not on the High Heat Watch List; therefore, no information needs are currently identified for this program element.

\subsubsection{Flammable Gas}

This tank is on the Flammable Gas Watch List. The applicable data quality objective (DQO) for this safety issue is Flammable Gas Safety Program: Data Requirements for Core Sample Analysis Developed through the Data Quality objectives Process (McDuffie 1995). However, the DQO states that core sampling of the single shell tanks that are part of the Flammable Gas Watch List is not planned at this time.

\subsubsection{Vapor}

A11 177 underground tanks must be vapor-sampled for organic solvent screening as per Recommendation 93-5 Implementation Plan (DOE-RL 1996). Some tanks may require additional vapor sampling due to other program needs. These tanks may be classified into four categories: (1) those tanks which are to be rotary mode core sampled (as a consequence of the rotary sampling system exhauster permit requirements); (2) tanks on the Organic or Ferrocyanide Watch Lists; (3) tanks in C farm; and (4) tank 241-BX-104, due to vapor exposure. Information needs must satisfy Data Quality Objectives for Tank Hazardous Vapor Safety Screening (Osborne and Buckley 1995), and for rotary mode only, Rotary Core Vapor Sampling Data Quality Objective (Price 1994) and Data Quality Objective for Regulatory Requirements for Hazardous and Radioactive Air Emissions Sampling and Analysis (Mulkey and Markillie 1995) as amended by Status of the Current Understanding of the Toxic Air Pollutants (TAPS) and Hanford Tank Farm Vapor Space Characterization; Recommended Path Fonward and Just ification for Cont inued RMCS Exhauster Operations (Laws 1996). (1995).

Tank S-111 was vapor sampled in March 1995 in support of Osborne et al. 
WHC-SD-WM-TP-317, REV 1

\subsubsection{Criticality}

No information separate from that for the general safety issue of tank S-111 are currently identified for this program element. However, if the general safety screening of tank $S-111$ identifies a potential criticality concern, analyses for fissile materials and neutron sorbers and poisons will be performed as identified in the safety screening DQO.

\subsection{CONTINUING OPERATIONS}

\subsubsection{Compatibility/Stabilization}

Tank S-111 will be sampled to determine waste compatibility. Sampling and analys is requirements must be performed per the Data Quality objectives for Tank Farms Waste Compatibility Program (Fowler, 1995). The analyses employed will be for transuranics such as ${ }^{239} \mathrm{Pu}$ and ${ }^{241} \mathrm{Am}$, TOC, and heat generation as determined by the amount of ${ }^{90} \mathrm{Sr}$ and ${ }^{137} \mathrm{Cs}$.

\subsubsection{Evaporator}

This section does not apply to tank S-111.

\subsection{DOUBLE-SHELL TANK WASTE ANALYSIS PLAN}

This section does not apply because tank $\$-111$ is a single-shell tank.

\subsection{DISPOSAL}

\subsubsection{Retrieval}

Current retrieval needs (Bloom and Nguyen 1995) do not call for test samples to be taken from tank $S-111$.

\subsubsection{Pretreatment/Vitrification}

Tank S-11l has not been identified as a bounding tank for pretreatment/ disposal process development strategy (Kupfer et al. 1995). All tanks were prioritized using the pretreatment strategy in the Tank Waste Characterization Basis (Brown et a1. 1995) document and a portion of archive sample material could be used for pretreatment testing if available. The strategy does not require any specific analyses to be done on the samples. 


\subsection{HISTORICAL MODEL EVALUATION}

This tank is identified as an acceptable alternative for bounding tank 241-S-107 (S-107) in Historical Model Evaluation Data Requirements (Simpson and McCain 1995). The applicability of these analyses will be determined based on tank S-107's sampling and analysis and will be documented in the tank specific sample and analysis plan.

\subsection{HOW INFORMATION WILL BE OBTAINED}

The number of samples required to characterize a tank is a function of waste heterogeneity and the desired confidence to make a correct decision. As directed by the safety screening $\mathrm{DQO}$, if inadequate information exists to determine an appropriate number of samples, two vertical profiles will be obtained. These vertical profiles may be obtained using core, auger (for shallow tanks), or grab samples. If analysis of these profiles reveals that additional profiles are necessary to meet data needs, more sample profiles will be requested. Prior to rotary sampling, it is necessary to vapor sample the tank per the requirements of Rotary Core Vapor Sampling Data Quality objective (Price 1994).

\subsection{PRIORITY OF INFORMATION REQUIREMENTS}

Vapor sampling was completed in March 1995. Push mode core sampling is scheduled to begin in May 1996. Grab sampling is scheduled to begin in June 1997 (Stanton 1996). Refer to Table 4-1 for the current DQO requirements and planned sampling and analytical requirements. 
WHC-SD-HM-TP-317, REV 1

Table 4-1: Integrated DQO Requirements and Priorities

\begin{tabular}{|c|c|c|c|}
\hline $\begin{array}{c}\text { Sampling } \\
\text { Event }\end{array}$ & Applicable Issues & Sampling Requirements & Analytical Requirements \\
\hline $\begin{array}{l}\text { Vapor } \\
\text { Sampling }\end{array}$ & $\begin{array}{l}\text {-Organic Solvent Layer } \\
93-5 \text { Vapor Issue } \\
\text {-Hazardous Vapor DQO }\end{array}$ & $\begin{array}{l}\text { Steel canisters, } \\
\text { Triple Sorbent Traps, } \\
\text { Sorbent Trap Systems }\end{array}$ & $\begin{array}{l}\text { Flammable Gas } \\
\text { Organic Vapors } \\
\text { Permanent Gases }\end{array}$ \\
\hline $\begin{array}{l}\text { Push Mode } \\
\text { Core } \\
\text { Sampling }\end{array}$ & $\begin{array}{l}\text {-Safety Screening DQO } \\
\text {-Organic Safety DQO } \\
\text {-Flammable Gas DQO } \\
\text { (See Section 2.2.4) }\end{array}$ & $\begin{array}{l}\text { Core samples from } 2 \\
\text { risers separated } \\
\text { radially to the } \\
\text { maximum extent } \\
\text { possible } \\
\text { Combustible gas } \\
\text { measurement }\end{array}$ & $\begin{array}{l}\text { Flammability, Energetics, } \\
\text { Moisture, Density, Total } \\
\text { alpha activity, Toc, } \\
\text { Separable organics }\end{array}$ \\
\hline $\begin{array}{l}\text { Grab } \\
\text { Sampling }\end{array}$ & -Compatibility DQO & Multiple grab samples & $\begin{array}{l}\text { Energetics, Moisture, } \\
\text { Cations, Anions, } \\
\text { Radionuclides, Specific } \\
\text { gravity, Percent solids, } \\
\text { pH, TOC, Total inorganic } \\
\text { carbon, Separable } \\
\text { organics }\end{array}$ \\
\hline
\end{tabular}

* Consult each applicable DQO in force at the time for sampling and analytical requirements.

\subsection{WHEN INFORMATION WILL BE AVAILABLE}

According to Stanton (1996), data are expected to be available from the grab sampling event for tank S-111 in October 1997. Data from the push mode core sampling are expected in September 1996. These times may be altered if the sampling schedule changes. Data are available from the March 1995 vapor sampling. 
WHC-SD-WM-TP-317, REV 1

\subsection{REFERENCES}

Bloom, G. R. and Q. H. Nguyen, 1995, Characterization Data Needs for Development, Design and Operation of Retrieval Equipment Developed Through the Data Quality Objective Process, WHC-SD-WM-DQO-008, Rev. 0, Westinghouse Hanford Company, Richland, Washington.

Brevick, C. H., L. A. Gaddis, and W. W. Pickett, 1994, Historical Tank Content Estimate Report for the Southwest Quadrant of the Hanford 200 West Areas, WHC-SD-WM-ER-352, Rev. 0, Westinghouse Hanford Company, Richland, Washington.

Brown, T. M., S. J. Eberlein, and T. J. Kunthara, 1995, Tank Waste Characterization Basis, WHC-SD-WM-TA-164, Rev. 1, Westinghouse Hanford Company, Richland, Washington.

D0E-RL, 1996, Recommendation 93-5 Implementation Plan, D0E/RL-94-0001, Rev. 1, U.S. Department of Energy, Richland, Washington.

Dukelow, G. T., J. W. Hunt, H. Babad, and J. E. Meacham, 1995, Tank Safety Screening Data Quality Objective, WHC-SD-WM-SP-004, Rev. 2, Westinghouse Hanford Company, Richland, Washington.

Fowler, K.D., 1995, Data Quality Objectives for Tank Farm Waste Compatibility Program, WHC-SD-WM-DQO-001, Rev. 1, Westinghouse Hanford Company, Richland, Washington.

Hanlon, B.M., 1996, Waste Tank Summary for Month Ending January 31, 1996, WHC-EP-0182-94, Westinghouse Hanford Company, Richland, Washington.

Kupfer, M. J., W. W. Schultz, and J. T. Slankas, 1995, Strategy for Sampling Hanford Site Tank Wastes for Development of Disposal Technology, WHC-SD-WM-TA-154, Rev. 1, Westinghouse Hanford Company, Richland, Washington.

Laws, G. L., 1996, Status of the Current Understanding of the Toxic Air Pollutants (TAPS) and Hanford Tank Farm Vapor Space Characterization; Recommended Path Forward and Just ification for Continued RMCS Exhauster Operations, (telephone conference memorandum 01830-96-022, to Distribution, March 8), Westinghouse Hanford Company, Richland, Washington.

McDuffie, N. G., 1995, Flammable Gas Tank Safety Program: Data Requirements for Core Sample Analysis Developed Through the Data Quality Objectives Process, WHC-SD-WM-DQ0-004, Rev. 2, Westinghouse Hanford Company, Richland, Washington.

Mulkey, C.H., and K. D. Markillie, 1995, Data Quality Objective for Regulatory Requirements for Hazardous and Radioactive Air Emissions Sampling and Analysis, WHC-SD-WM-DQ0-021, Rev. 0, Westinghouse Hanford Company, Richland, Washington. 
Osborne, J. W., and L. L. Buckley, 1995, Data Quality Objectives for Tank Hazardous Vapor Safety Screening, WHC-SD-WM-DQO-002, Rev. 2, Westinghouse Hanford Company, Richland, Washington.

Osborne, J. W., J. L. Huckaby, and E. R. Hewitt, 1995, Data Quality Objectives for Generic In-Tank Health and Safety Vapor Issue Resolution, WHC-SD-WMDQ0-002, Rev. 1, Westinghouse Hanford Company, Richland, Washington.

Price, D. N., 1994, Rotary Core Vapor Sampling Data Quality Objective, WHC-SD-WM-SP-003, Rev. O, Westinghouse Hanford Company, Richland, Washington.

Simpson, B. C., and D. J. MCCain, 1995, Historical Model Evaluation Data Requirements, WHC-SD-WM-DQ0-018, Rev. OA, Westinghouse Hanford Company, Richland, Washington.

Stanton, G. A., Baseline Sampling Schedule, Change 96-02 (Internal memo 75610-96-06, to Distribution, Apri1 17), Westinghouse Hanford Company, Richland, Washington.

Turner, D. A., H. Babad, L. L. Buckley and J. E. Meacham, 1995, Data Quality Objective to Support Resolution of the Organic Complexant Safety Issue, WHC-SD-WM-DQ0-006, Rev. 2, Westinghouse Hanford Company, Richland, Washington. 


\begin{tabular}{|c|c|c|c|c|c|}
\hline \multicolumn{6}{|c|}{ DISTRIBUTION SHEET } \\
\hline To & \multirow{2}{*}{\multicolumn{3}{|c|}{$\begin{array}{l}\text { From } \\
\text { Evaluation and Planning }\end{array}$}} & \multicolumn{2}{|l|}{ Page 1 of 1} \\
\hline Distribution & & & & \multicolumn{2}{|c|}{ Date $\quad 05 / 09 / 96$} \\
\hline \multicolumn{4}{|l|}{ Project Title/Work Order } & \multicolumn{2}{|c|}{ EDT No. N/A } \\
\hline \multicolumn{4}{|c|}{$\begin{array}{l}\text { WHC-SD-WM-TP-317, Rev. 1, "Tank 241-S-111 Tank Characterization } \\
\text { Plan" }\end{array}$} & \multicolumn{2}{|c|}{ ECN No. ECN-631559 } \\
\hline Name & MSIN & $\begin{array}{c}\text { Text } \\
\text { With } \\
\text { Al1 } \\
\text { Attach. }\end{array}$ & Text Only & $\begin{array}{l}\text { Attach./ } \\
\text { Appendix } \\
\text { Only }\end{array}$ & $\begin{array}{l}\text { EDT/ECN } \\
\text { Only }\end{array}$ \\
\hline
\end{tabular}

ONSITE

U. S. Department of Energy Richland Field Office

W. Liou

N. W. Willis

$\begin{array}{ll}57-54 & x \\ 57-54 & x\end{array}$

Westinghouse Hanford Company

J. M. Conner

G. D. Forehand

C. S. Homi

Central Files

T.C.R.C.

$\begin{array}{ll}\text { R2 }-12 & x \\ \text { S7 }-21 & x \\ \text { R2 }-12 & x \\ \text { A3 }-88 & x \\ \text { R2 }-12 & x\end{array}$

\section{OFFSITE}

U. S. Department of Enerqy - Headquarters

Office of Environmental Restoration and

Waste Management EM-563

12800 Middlebrook Road

Germantown. MD 20874

J. A. Poppiti

$X$ 